\title{
66 \\ PERAN PEKERJA SOSIAL DI PERINDUSTRIAN INDONESIA
}

Oleh :

Aries Y. Ahmadi, Hadiyanto A. Rachim, \& Moch Zaenuddin

Email:

ariesyudieahmadi@gmail.com; hrachim@gmail.com; moch.zainuddin@yahoo.com

\begin{abstract}
ABSTRAK
Pekerjaan sosial industri adalah lapangan praktik pekerja sosial yang secara khusus menangani kebutuhan-kebutuhan kemanusiaan dan sosial di dunia kerja melalui berbagai intervensi dan penerapan metode pertolongan yang bertujuan untuk memelihara keseimbangan antara individu dan lingkungan kerja dalam konteks ini. Konsep pekerjaan sosial industri bukan hanya berbicara tentang konsep tanggung jawab sosial perusahaan (CSR) maupun masyarakat (community development) saja. Pekerjaan sosial industri mencangkup pelayanan sosial yang bersifat internal dan eksternal, pekerjaan sosial industri melibatkan program-program bantuan bagi pegawai, seperti pelayanan konseling terapi kelompok, dan pengembangan sumber daya manusia. Secara eksternal, pekerjaan sosial industri, berwujud dalam berbagai bentuk program CSR termasuk di dalamnya strategi dan program pengembangan masyarakat serta kebijakannya, dan advokasi sosial. Kehadiran pekerja sosial di perindustrian diharapkan akan memerikan berbagai manfaat terutama manfaat secara finansial maupun secara sosial. Di Indonesia, istilah pekerjaan sosial dalam perindustrian masih belum banyak dikenal, belum banyak perusahaan yang mengunakan jasa pekerja sosial di dalamnya. Sementara itu di era globalisasi ini, bayak perusahaan-perusahaan di beberapa negara maju yang sudah sejak lama mengunakan konsep pekerjaan sosial di dalam perusahaannya, sehingga bisa meningkatkan kualitas perusahaan tersebut dan juga bisa bermanfaat bagi masyarakat.
\end{abstract}

Kata Kunci : Pekerja Sosial Industri, Peran Pekerja Sosial internal dan eksternal, Industri di Indonesia

\section{PENDAHULUAN}

Dewasa ini seiring dengan berjalannya waktu, globalisasi di bidan perindustrian semakin gencar saja. Banyak perusahaan-perusahaan berlomba-lomba mencari cara untuk lebih meningkatkan kualitasnya. Berbagai konsep dalam perusahaan terus dicoba dan diterapkan agar mereka menjadi yang terbaik. Salah satu konsep yang dianggap bisa mendorong terjadinya perubahan dan suatu kemajuan dalam keberlangsungan perusahaan adalah konsep pekerjaan sosial industri

Pekerjaan sosial industri adalah lapangan praktik pekerja sosial yang secara khusus menangani kebutuhan-kebutuhan kemanusiaan dan sosial di dunia kerja melalui berbagai intervensi dan penerapan metode pertolongan yang bertujuan untuk memelihara keseimbangan antara individu dan lingkungan kerja dalam konteks ini. 
Konsep pekerjaan sosial industri lebih luas dari konsep tanggung jawab sosial perusahaan (CSR) maupun pengembangan masyarakat (community development). Pekerjaan sosial industri mencangkup pelayanan sosial yang bersifat internal dan eksternal, pekerjaan sosial industri melibatkan program-program bantuan bagi pegawai, seperti pelayanan konseling, K3 (Keselamatan dan Kesehatan Kerja), perencanaan sebelum dan sesudah pensiun, pembelaan karyawan dan keluarga (affirmatif), terapi kelompok, dan pengembangan sumber daya manusia. Secara eksternal pekerjaan sosial industri berwujud dalam berbagai bentuk program CSR termasuk di dalamnya strategi dan program pengembangan masyarakat, pengembangan kebijakan sosial, dan advokasi sosial.

Johnson (1984:261) mengklasifikasikan akibat-akibat industrialisasi yang bersifat negatif terhadap kesejahteraan manusia kedalam 5A, yaitu alienation, alcoholism, absenteeism, accidents, dan abuse. Beberapa permasalahan tersebut tentunya menjadi permasalahan sosial di linkungan kerja, pekerja sosial sebagen agen perubahan dapat berperan aktif membantu perusahaan dan khususnya para pegawainya menyelesaikan berbagai permasalahan tersebut.

Bidang bisnis dan berbagai perindustrian di Indonesia sebagai mana kita ketahui sampai saat ini belum banyak yang mengunakan jasa pekerja sosial dalam divisi yang terkait dengan kapasitas dan kompetensi pekerja sosial. Bahkan posisi atau divisi yang sudah seharusnya ditempati oleh para pekerja sosial di perusahaan-perusahaan dan berbagai industri, justru sudah banyak sesak diisi oleh SDMnya, tetapi mereka bukan dari pekerja sosial.

Di Indonesia, dunia bisnis dan industri merupakan sektor yang masih jarang melibatkan pekerjaan sosial. Namun demikian, di negara-negara maju seperti AS, Inggris, Australia dan New Zealand, pemberian pelayanan sosial dalam perusahaan telah meningkat secara dramatis selama tiga dekade belakangan ini. Pekerjaan sosial industri atau pekerjaan sosial di perusahaan (occupational social work) merupakan profesi yang sangat penting dalam pemberian pelayanan sosial, baik yang bersifat pencegahan, penyembuhan maupun pengembangan. Pekerjaan sosial industri muncul di Amerika Serikat satu abad lalu. Di Eropa, bidang ini muncul pada tahun 1920an. Pekerjaan sosial memang terlahir dalam konteks pertumbuhan masyarakat industri (Suharto,2006).

Berbanding lurus dengan minimnya pekerja sosial di dalam dunia bisnis dan industri di Indonesia, masih banyak sektor bisnis dan perindustrian yang fokus pada profit tanpa terlalu memperhatikan kesejahteraan pegawai serta lingkungan kerja dan sekitarnya. Seperti kita ketahui, tidak sedikit kasus-konflik yang melibatkan berbagai perusahaan atau perindustrian dengan pekerja ataupun dengan masyarakat yang dikarenakan adanya ketidak sesuaian antara perusahaan atau perindustrian degan lingkungan kerja dan sekitarnya.

Adapun maksud dan tujuan penulus dari pengambilan judul tema Pekerja Sosial di Bidang Perindustrian Indonesia ini, adalah untuk lebih memeperkuat alasan tentang bagaimana pentingnya peran pekerja sosial dalam dunia bisnis dan industri di Indonesia. Dengan pengetahuan, keterampilan dan nilai-nilai pekerjaan sosial, pekerja sosial di bidang bisnis dan industri diharapkan bisa memberikan berbagai keuntungan baik dari profit maupun sosial, dengan pelayanan-pelayanan yang diberikan.

\section{PEMBAHASAN}

Di Indonesia, istilah pekerjaan sosial dalam perindustrian masih belum banyak dikenal oleh banyak perusahaan-perusahaan, serta oleh masyarakat luas. Belum banyak perusahaan yang mengunakan jasa pekerja sosial di dalamnya. Sementara itu di era globalisasi ini, bayak perusahaanperusahaan yang sudah sejak lama mengunakan konsep pekerjaan sosial di dalam perusahaannya. Sehingga bisa meningkatkan kualitas perusahaan tersebut.

Bidang garapan pekerjaan sosial industri meliputi sektor internal dan eksternal. Sektor internal meliputi pelayanan konseling, K3 (kesehatan dan keselamatan kerja), manajemen sumber daya manusia, layanan pembelaan pegawai dan keluaganya, perencanaan sebelum dan sesudah pensiun 
dan lainnya. Sedangkan pada sektor eksternal ada yang dinamakan dengankonsep tanggung jawab sosial perusahaan atau Coorporate Social Responsibility (CSR).

Berbagai pelayanan yang diberikan oleh pekerja sosial industri dalam lingkup internal yang ditujukan oleh para pegawai sudah seharusnya mulai diterapkan oleh berbagai perusahaan. Khususnya di Indonesia ini yang kebanyakan perusahaan dan berbagai sektor bisnis di bidang industrinya belum banyak mengenal konsep pekerjaan sosial industri. Memang pada faktanya di Indonesia penerapan pekerjaan sosial di lingkup eksternal lebih populer dengan konsep tanggung jawab sosial perusahaan atau Coorporate Social Responsibility (CSR) yang banyak dijalankan oleh banyak perusahaan. Tetapi perusahaan juga harus memperhatikan lingkup internal perusahaan dan harus memastikan kesejahteraan bagi pegawai.

Lingkungan dan juga suasana kerja yang kondusif, keadaan psikis pegawai yang terjamin dalam keadaan yang baik dan kesejahteraan pegawai merupakan hal -hal utama dalam kesuksesan dan untuk semakin berkembangnya suatu perusahaan. Tetapi tidak selamanya keadaan internal suatu perusahaan selalu terjamin dalam keadaan yang baik-baik saja, sewaktu-waktu pegawai bisa saja merasa jenuh, tertekan karena pekerjaan, berada dalam keadaan yang sulit karena permasalahan dalam keluarganya, timbal balik dari perusahaan tidak sesuai dengan tenaga yang dikeluarkan dan juga permasalahan lainnya yang dapat menyebabkan kondisi atau suasana kerja menjadi sangat tidak kondusif dan tidak menyenangkan sehingga menyebabkan kemunduran prestasi dan produktifitas kerja yang berdampak kepada menurunnya kualitas perusahaan.

Johnson (1984:261) mengklasifikasikan akibat-akibat industrialisasi yang bersifat kesejahteraan manusia kedalam 5A, yaitu:

1. Alienation: perasaan keterasingan dari diri, keluarga dan kelompok sosial yang dapat menimbulkan apatis, marah, dan kecemasan.

2. Alcoholism atau Addiction: ketergantungan terhadap alkohol, obat-obat terlarang atau rokok yang dapat menurunkan produktifitas, merusak kesehatan fisik dan psikis, dan kehidupan sosial seseorang.

3. Absenteeism: kemangkiran kerja atau perilaku membolos kerja dikarenakan rendahnya motivasi pekerja, perasaan-perasaan malas, tidak berguna, tidak merasa memiliki perusahaan, atau sakit fisik dan psikis lainnya.

4. Accidents: kecelakaan kerja yang diakibatkan oleh menurunnya konsentrasi pekerja atau oleh lemahnya sistem keselamatan dan kesehatan lingkungan kerja.

5. Abuse: bentuk-bentuk perlakuan salah terhadap anak-anak atau pasangan dalam keluarga (istri/suami), seperti memukul dan menghardik secara berlebihan yang ditimbulkan oleh frustrasi, kebosanan dan kelelahan di tempat pekerjaannya.

Beberapa permasalahan sosial lainnya yang terkait dengan industrialisasi adalah: diskriminasi di tempat kerja atau tindakan-tindakan tidak adil terhadap wanita, kaum minoritas, imigran, remaja, pensiunan, dan para penyandang cacat. Beberapa industri dan perusahaan juga kerap menimbulkan dampak negatif terhadap masyarakat di sekitarnya, seperti polusi (udara, air, suara) dan kerusakankeusakan fisik dan psikis bagi para pekerjanya.

Diterangkan Johnson dengan jelas dalam klasifikasi akibat-akibat industrialisasi, bahwa berbagai permasalahan mungkin akan terjadi kapan saja menimpa perusahaan. Alienation atau perasaan keterasingan, sangat mungkin terjadi pada kalangan pekerja yang bekerja di dalam perusahaan yang menerapkan sistem dengan jam kerja yang lama, bekerja dalam ruangan yang tertutup seluruhnya, berhadapan dengan mesin dan kurang berkomunikasi dengan sesama pekerja lainnya. Perasaan jenuh akan pekerjaannya sewaktu-waktu akan datang dengan kondisi seperti ini. Pekerja akan merasa terasing dari kehidupan keluarga, lingkungan rumah dan lingkungan sosial lainnya. 
Dalam kasus ini, pekerja sosial dapat berperan sebagai pemberi pelayan konseling menangani pekerja dengan kasus perasaan keterasingan atau Alienation ini. Layanan konseling ini bertujuan membantu pekerja yang mempunyai masalah, dan membantu klien untuk dirinya menemukan kembali keberfungsian sosialnya karena waktu sehari-harinya hanya mengurus pekrejaannya.

Tekanan kerja yang tinggi juga bisa menimbulkan pekerja melakukan perlakuan yang menyimpang, seperti melampiaskannya dengan meminum minuman keras, ketergantungan kepada obat-obatan ataupun konsumsi rokok yang berlebih (Alcoholism atau Addiction). Dalam kasus ini, pekerja sosial dapat berperan dengan mengintervensi para pekrja dengan menggunakan terapi kelompok, untuk menagani permasalahan-permasalahan yang telah disebutkan diatas. Karena dalam lingkungan kerja, pekerja akan bekerja sama, berinteraksi dalam suatu kelompok dalam teman kerjanya. Maka dari itu peksos dapat mengumpulkan para pekerja dalam satu lingkungan kerja yan bermasalah dengan minuman keras, ketergantungan kepada obat-obatan ataupun konsumsi rokok yang berlebih (Alcoholism atau Addiction) untuk bersama mengembalikan keberfungsian sosialnya, untuk mencegah perbuatan ini (Alcoholism atau Addiction) terus terjadi dan mengarahkan pegawai agar bisa lebih mengintrospeski dirinya sendiri.

Perasaan jenuh pada saat bekerja pastinya akan atau pernah dialami oleh para pekerja di suatu perusahaan. Perasaan jenuh itu dapat diekspresikan dengan bekerja dengan malas, frustasi akan pekerjaan yang begitu banyak, hingga menderita sakit karena pekerjaan dan bahkan sampai membolos kerja (Absenteeism). Dampak dari itu, akhirnya akan merugikan perusahaan dan juga tentunya akan merugikan diri sendiri yang mungkin akan mendapatkan sanksi dari perusahaan apabila absen karena alasan yang tidak jelas dan kuat. Pekerja sosial dalam konteks masalah ini, dapat mengintervensi pekerja yang mengalami masalah dengan cara melakukan strategi penanganan Burnout dan Stress. Strategi tersebut bisa dilakukan dengan berbagai variasi program penanganannya, seperti mengagendakan kegiatan-kegiatan diluar pekerjaan kepada perusahaan, seperti menjadwalkan kegiatan relaksasi, olahraga, rekreasi, variasi kerja, dan kegiatan lainnya yang membuat suasanalingkungan kerja menjadi menyenangkan dan membuat pekerja lebih bersemangat.

Selain permasalahan yang telah dibahas sebelumnya, salah satu permasalahan yang seringkali terjadi dalam dunia kerja adalah permasalahan kecelakaan kerja (Accidents). Isu tentang Kesehatan dan Keselamatan Kerja (K3) menjadi salah satu isu yang seringkali diperbincangkan dalam dunia perindustrian di Indonesia. Menurut data ILO (International Labour Organization) pada tahun 2013 saja tercatat setidaknya 9 orang meninggal dalam kecelakaan kerja, dan di Indonesia rata-rata per tahun terdapat 99.000 kasus kecelakaan kerja. Dari total jumlah itu, sekitar 70 persen berakibat fatal yaitu kematian dan cacat seumur hidup.

Melihat angka tersebut memang sangat mencengangkan, tentunya banyak pertanyaan yang muncul. Apakah standar K3 yang diterapkan oleh berbagai perusahaan dan perindustrian di Indonesia sangatlah rendah ? Apakah kesadaran para pegawai tentang savety work dengan memakai perlengkapan keselamatan kerja begitu kurang pula ?.

Resiko kecelakaan kerja dan juga penyakit yang disebabkan oleh kelalaian kerja tidak hanya menimpa pekerja saja, tetapi bagi perusahaan atau industri yang dekat dengan lokasi pemukiman, bukan tidak mungkin resiko adanya korban dari pihak warga sekitar. Maka dari itu, menurut penulis perlu adanya profesi medis yang selalu siap kapan pun di lokasi perusahaan untuk mengantisipasi hal yang tidak diinginkan. Selain itu perusahaan melalui pelayanan pekerja sosialnya harus gencar melakukan sosialisasi kepada pegawai maupun waraga di lingukngan sekitar perusahaan akan K3 ini.

Pekerja sosial harus memahami apa saja dampak yang disebabkan oleh kecelakaan dan berbagai penyakit yang timbul dalam dunia kerja, serta membantu pegawai beserta keluarganya agar bisa menerima dan mampu menghadapi akibat-akibat yang akan timbul. Misalnya pekerja sosial mencarikan jaminan sosial bagi pegawai yang tidak dapat meneruskan pekerjaannya, melakukan perubahan-perubahan di tempat kerja, atau memperluas akses terhadap pelayanan-pelayan 
rehabilitasi dan pelatihan kejuruan terutama bagi pegawai yang ingin kembali ke tempat bekerjanya semula (Suharto, 2009 : 77).

Kasus terakir yang terkait permasalahan-permasalahan dalam industrialisasi yang bersifat kesejahteraan manusia adalah permasalahan pekerja dengan keluarganya. Seringkali pekerja yang bermasalah dengan keluarga menunjukan prestasi yang kurang baik dan tidak maksimal dalam bekerja. Atau pun sebaliknya, pekerja yang mempunyai tekanan kerja yang tinggi sering kali melampiaskannya kepada orang-orang yang ada dirumahnya, yaitu keluarganya. Tindakan yang dilakukan dapat berupa perlakuan salah terhadap anak-anak atau pasangan dalam keluarga (istri/suami), seperti memukul dan menghardik secara berlebihan (Abuse). Dalam hal ini pekerja sosial dapat melakukan intervensi dengan menggunakan terapi kelompok dan peksos sebagai fasilitator, untuk mencegah terjadinya permasalahan-permasalahan tindakan Abuse. Dengan menggunakan terapi kelompok, para pekerja dikumpulkan dalam kelompok untuk menyampaikan keluh-kesahnya secara bergiliran, dan diharapkan dalam kelompok ini dapat berbagai solusi untuk menyelesaikan berbagai permasalahan yang timbul akibat pekerjaannya.

\section{CSR (Coorporate Social Responsibility)}

Konsep Tanggung Jawab Sosial Perusahaan (Corporate Social Responsibility) yang kini menjadi isu sentral yang semakin populer di kalangan perusahaan. Oleh karena itu semakin banyak pula kalangan dunia usaha dan pihak-pihak terkait mulai merespon wacana ini, tidak sekedar mengikuti tren tetapi dapat memahami dampak positif dan berbagai manfaatnya baik itu untuk perusahaan maupun manfaat bagi masyarakat. Program CSR merupakan investasi bagi perusahaan demi pertumbuhan dan keberlanjutan perusahaan dan bukan lagi dilihat sebagai sarana biaya melainkan sebagai sarana meraih keuntungan. Program CSR merupakan komitmen perusahaan untuk mendukung terciptanya pembangunan berkelanjutan (sustainable development)

Penerapan program $C S R$ oleh suatu perusahaan atau perindustrian mencakup berbagai kegiatan dan tujuannya adalah untuk mengembangkan masyarakat yang sifatnya produktif dan melibatkan masyarakat didalam dan diluar perusahaan baik secara langsung maupun tidak langsung. Sebagai contoh kegiatan programCSR yang dilakukan oleh beberapa perusahaan yang ada di Indonesia seperti, program WASH (Water Access, Sanitation, Hygiene Program) tujuanya untuk memberikan solusi dalam penyediaan air bersih di Indonesia yang dilaksanakan di NTT, Pertamina Scholarship (Beasiswa) Diberikan kepada 1.450 Siswa di Jabodetabek, 300 mahasiswa diploma di Padang, Palembang, dan Solo, Beasiswa S-2 untuk 25 PNS Non-Dosen, dan 25 pegawai DESDM, Beasiswa 10 Siswa terbaik untuk menempuh pendidikan tinggi di ITB, S2 Luar Negeri, dan Beasiswa untuk 100 Siswa Madrasah, dan masih banyak perusahaan lainnya yang telah sadar melakukan program $C S R$.

Pengertian CSR diadaptasi dari Pasal 1 butir 3 Undang-Undang Nomor 40 Tahun 2007 Tentang Perseroan Terbatas, yang menyebutkan komitmen perseroan untuk berperan serta dalam pembangunan ekonomi berkelanjutan guna meningkatkan kualitas kehidupan dan lingkungan yang bermanfaat, baik bagi perseroan sendiri, komunitas setempat maupun masyarakat pada umumnya. (Widjaja dan Ardi Pratama, 2008: 7)

Perusahaan memberikan kontribusi sosial yang biasanya bersifat materil dan berbagai program-programnya, diharapkan mampu mengembangkan serta bisa membangun masyarakat dari berbagai bidang. Perusahaan pun tidak bisa memungkiri bahwa CSR ini merupakan salah satu strategi mereka untuk mendekatkan diri dengan masyarakat.

Konsep CSR begitu identik dengan metode Community Development atau pengembangan masyarakat serta pemberdayaan masyarakat.Perserikatan Bangsa-Bangsa menurut Einsiedel (dikutip dalam Suharto, 1997: 98) mendefinisikan pembangunan masyarakat merupakan suatu 'proses' dimana usaha-usaha atau potensi-potensi yang dimiliki masyarakat diintegrasikan dengan sumber daya yang dimiliki pemerintah, untuk memperbaiki kondisi ekonomi, sosial dan kebudayaan, dan 
mengintegrasikan masyarakat di dalam konteks kehidupan berbangsa, serta memberdayakan agar mampu memberikan kontribusi secara penuh untuk mencapai kemajuan pada level nasional.

Pekerja sosial dalam konteks CSR, melakukan community development dan segala bentuk yang diberikan oleh perusahaan kepada masyarrakat adalah untuk membantu masyarakat atau penerima bantuan memiliki kemampuan untuk menolong atau memberdayakan dirinya sendiri dan lingkungannya.

\section{Manfaat Pekerja Sosial Industri Bagi Keberlangsungan Perusahaan Perindustrian di Indonesia}

Dampak globalisasi begitu terasa pada kehidupan manusia, manusiapun semakin berkembang pesat dengan berbagai inovasinya di berbagai sektor kehidupan. Begitupun dengan profesi pekerjaan sosial, perkembangan bidang sasaran dan intervensi pekerjaan sosial di Indonsia khusunya semakin hari semakin berkembang luas. Perkembangan di dunia industri pun menjadi sebuah peluang bagi pekerja sosial. Semakin berkembangnya pemikiran-pemikiran pengusaha mengenai berbagai cara untuk memajukan perusahaannya. Di Indonesia pekerja sosial Industri memanglah masih relatif baru dan belum begitu populer.

Pada saat ini dunia industri sudah bisa merasakan manfaat dari adanya pekerja sosial industri. Manfaatnya berorientasi kepada keuntungan secara finansial maupun secara sosial. Keuntungan secara finansial karena pekerja sosial dapat menangani berbagai bidang garapan yang diantaranya bermanfaat kepada meninkatnya kinerja pegawai sehingga lebih produktif dan lebih menguntungkan secara finansial. Sedangkan keuntungan dari aspek sosialnya adalah pekerja sosial di industri bisa menciptakan suasana kerja yang kondusif dengan intervensi-intervensi yang dilakukan kepada pegawai, dan selain itu dapat menjaga hubungan baik denagan masyarakat melalu kontribusi pada program $C S R$.

\section{Kesimpulan}

\section{PENUTUP}

Pekerjaan sosial di seputar dunia kerja atau yang disebut pekerja sosial industri di Indonesia memanglah belum begitu populer, tetapi penerapan pekerjaan sosial industri di suatu perusahaan sangatlah akan mendatangkan keunungan tersendiri, selain dari segi finansial, juga keuntungan dari segi sosial. Pekerjaan sosial industri mencangkup pelayanan sosialyang bertujuan menyelesaikan berbagai permasalahan yang disebabkan oleh industrialisasi. Peran pekrja sosialdi perusahaan adalah pada sektor internal dan eksternal, pekerjaan sosial industri melibatkan program-program bantuan bagi pegawai, seperti pelayanan konselingterapi kelompok, dan pengembangan sumber daya manusia. Secara eksternal, pekerjaan sosial industri, berwujud dalam berbagai bentuk program CSR atau tanggung jawab sosial perusahaan yang berbentuk berbagai bantuan program pengembangan masyarakat, dan berbagai bantuan lainnya yang bersifat sustainable development atau pembangunan berkelanjutan.

\section{Rekomendasi}

Mengingat pentingnya peran pekerja sosial di dunia kerja atau dunia perindustrian, maka akan lebih baik jika berbagai perusahaan dan perindustrian di Indonesia menempatkan pekerja sosial dalam divisi yang terkait.

Peran pekerja sosial sesuai dengan 4 sistem dasar pekerjaan sosial (Wibhawa B., Raharjo S., Budiarti M. : 53 ) yaitu sistem pelaksana perubahan dimana pekerja sosial industri menjadi agen perubahan. Sedangkan sistem kliennya adalah perusahaan, dimana secara sadar menginginkan suatu perubahan yang akan datang, yang dilakukan oleh agen peerubahan. Untuk sistem sasarannya adalah pekrja dari suatu perushaan, dimana diperlukan suatu perubahan agar bisa membuat perusahaan lebih baik karena kinerja dan kerja keras pegawainya. Sedangkan sistem kegiatannya adalah pemerintah, 
karena pemerintah sebagai pemangku kebijakan, demi terjadinya suatu perubahan dengan kebijakan yang dikeluarkan mengenai penerapan pekerjaan sosial industri pada suatu perusahaan.

\section{DAFTAR PUSTAKA}

\section{Sumber Buku :}

Suharto, Edi (2009). Pekerjaan Sosial di Dunia Industri : Memperkuat CSR. Bandung : Alfabeta Tanajaya, Jimmy. 2004. Tanggung Jawab Sosial Koporasi. Surakarta : BWI

Suharto, Edi. (2005) . Membangun Masyarakat Memberdayakan Rakyat. Bandung : Humaria Wibawa, Budhi dkk. 2010. Dasar-Dasar Pekerjaan Sosial. Bandung: Widya Padjadjaran Johnson, Wayne (1984), The Social Services: An introduction, New York: FE Peacock Rudito. Bambang dkk. 2003. Akses Peran Masyarakat “ Lebih Jauh Memahami Community Development". Jakarta : ICSD

Jim Ife. 2006 Community Development . Yogyakarta : Pustaka Belajar.

\section{Jurnal, Hasil Penelitian, Artikel:}

http://www.scribd.com/doc/249462459/K3-Industri\#force_seo/ (13-12-2014;22.20)

http://www.policy.hu/suharto/modul_a/makindo_26.htm (14-12-2014;14.30)

http://kertyawitaradya.wordpress.com/2010/01/26/tinjauan-teoritis-community-development/ (1512-2014; 16.00)

http://kesos.unpad.ac.id/?p=578 (14-12-2014 : 23.33) 